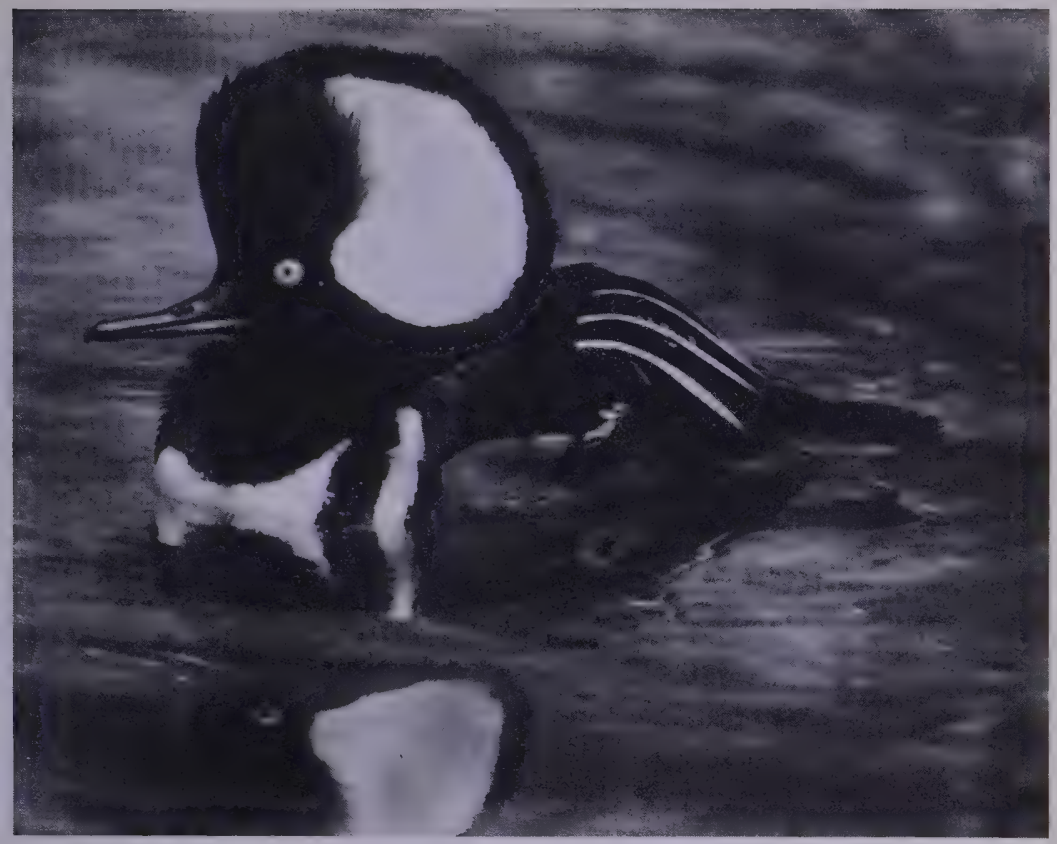

\title{
A FORK-TAILED FLYCATCHER AT DRUMHELLER, ALBERTA
}

JIM A. WEDGWOOD, 610 Leslie Avenue, Saskatoon, Saskatchewan. S7H 272

The "Golden Eagles," senior citizens from the Saskatoon Natural History Society, visited Drumheller, Alberta, on 1 June 1988 and in the evening a few members briefly birded the McMullen Island Picnic Area. There, F. Hartley Fredeen, Thelma V. Pepper and I observed a Forktailed Flycatcher (Tyrannus savana), a rare vagrant from South America. ${ }^{17}$

As the species was not on documented, confirmed or hypothetical lists for any of the western provinces, the bird was the first recorded in the West. ${ }^{113}$ It was Canada's sixth record?
The site, by the McMullen Island access road in Midland Provincial Park, was about $400 \mathrm{~m}$ from the junction with North Dinosaur Trail. It was beside the Red Deer River about $50 \mathrm{~m}$ south of a maintenance shed. Vegetation was shrub willows along the shore, mixed scrub thickets above the bank, and riverine cottonwoods and poplars; across the narrow river were sagebrush flats and arid hillsides.

Hearing unfamiliar calls upon arrival, the group started to track down this first mystery bird (eventually found to be a 
Yellow-breasted Chat - rarity enough for birders from the extreme north of the Great Plains). Concurrently, the three of us noticed an exceptionally long-tailed black and white bird in a nearby dead tree top. Yet another ubiquitous magpie was the reaction. However, major differences were obvious _ "a longish tail fluttering in the breeze ... black and white plumage. I thought of a magpie but this bird was all white below and smaller" (Fredeen). Wë had a second mystery bird.

Hartley viewed the bird from a hillock to the northeast; Thelma and I edged closer to it from the northwest, pausing to observe. At $30 \mathrm{~m}$ we studied the bird for about 2 minutes before it flew off. As we had to break away, our attempt to relocate the stranger was brief; early next morning the entire party hunted for it unsuccessfully. The bird atlas surveyor for the Drumheller zone, Ross Dickson, Calgary, scoured the district on 4-5 June, locating the chat, but not the flycatcher. ${ }^{5}$

Observations aggregated about $5 \mathrm{~min}$ utes; the time was 8:50 p.m. (on 1 June sunset at Drumheller was 9:41 p.m. local time.) ${ }^{18}$ Conditions were ideal: breeze light, sky clear, lighting mainly to front and side, lines of sight unobstructed. Only the upper part of the bird's back could not be seen fully. Because our viewing angle shifted as we approached, our perspective of the bird ranged from quarter-rear to quarter-front.

Head outline and bill shape were a flycatcher's, body size and posture a kingbird's. One's attention was repeatedly drawn to the tail: it was much longer than the usual small bird's and considerably exceeded body length. Although the tail was deeply, yet narrowly forked, no scissoring movement was noticed. Each element of the bifurcation was built up of layered, progressively longer feathers, as on a Scissor-tailed Flycatcher. A jet-black cap similar to an Eastern Kingbird's extended below the eye and into the nape. Wings and tail were a gray-black, with no wing bars or banding. The portion of the back that could be seen appeared darkish. Con- trasting sharply with the black cap were throat, side of neck around to the nape, and breast and belly, dazzling white in the lowering sun. The underparts had no bars, streaks or suffusions. No call, alarm or song notes were heard.

Reference to the National Geographic Society field guide indicated a Forktailed Flycatcher. ${ }^{17}$ Two differences, however, were noted: throat and neck were pure white on the observed bird, not off-white as illustrated, and, as for a female or moulter, tail length was threequarters of that portrayed. A photograph in the Audubon Society's Master Guide better accorded with the observations, particularly in depicting pure white below the cap and showing wing coverts only a shade lighter than primaries and secondaries. ${ }^{6}$ The tail was longer than that on the immature sketched in the Master Guide. Based on tail length and also on colour tones, the Drumheller bird was deemed to be an adult.

Similar species? An accidental vagrant in Alberta and a species familiar to me from Texas birding, the Scissor-tailed Flycatcher, has other features in common with the fork-tail besides a resemblance in tails. ${ }^{16}$ Colours and patterns, however, are profoundly unalike. Besides other affinities, the Eastern Kingbird and fork-tail are akin in size and in the distribution of black and white, yet tails differ basically in structure, length and banding.

The subspecies that is believed to throw off vagrants into North America ranges east of the Andes from northern South America to Argentina. ${ }^{15}$ This highly migratory southernmost population nests south to Patagonia, in semiarid habitats, and winters across the north of that continent, moving into the tropical zone at the end of the breeding season in austral fall (our spring). Rarely, a few birds fly to North America, where most reports are of vagrants wandering in the northern fall into southern and eastern United States. In eastern Canada the fork-tail is classed as an accidental. ${ }^{7}$ Thus this flycatcher's presence in Alberta on 1 June strained belief. The 


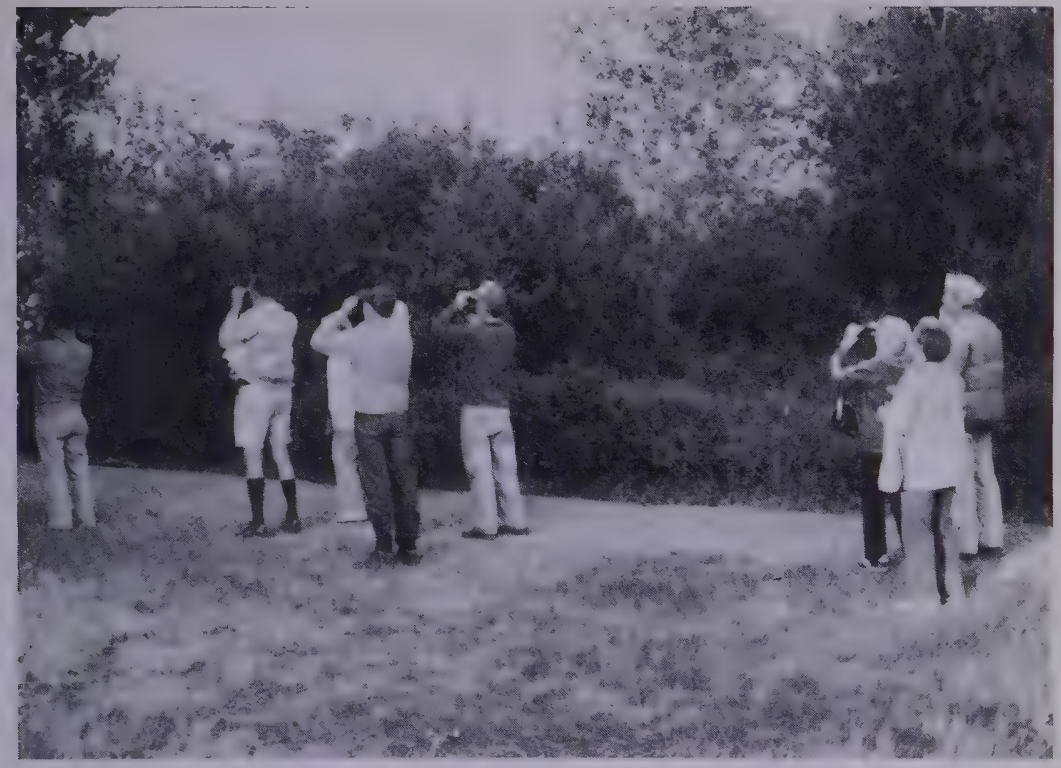

The Golden Eagles at Drumheller, Alberta.

Jim Pepper

usual hypotheses advanced to explain extralimital occurrences are cage escapees, abnormality causing wandering or lack thereof, weather-influenced movements, mass irruptions or random wandering normal for the species. A study of records and environmental conditions provided some rationale for the Drumheller bird.

The number of these birds reaching the United States and Canada is extremely small. Monroe and Barron listed only 40 records from the early 1800 s to 1978. ${ }^{12}$ Just four were in Canada: one at Thunder Bay - the only previous Canadian interior record - one in $\mathrm{New}$ Brunswick and two in Nova Scotia. Of the U.S. records only two, in Michigan and Wisconsin, were in the interior. Excepting a lone California report, all the rest were from south and east coast regions, with two-thirds of them in the Maryland-Nova Scotia zone. Over the last 40 years, reports per decade remained constant in the Gulf coast region, while increasing in this northern Atlantic coast zone from two in the $1940 \mathrm{~s}$ to 12 in the 1970s. Unknown is the extent to which this increase either mirrors bird movements or reflects improvement in information gathering.

Fork-tails in North America were believed to be birds which overflew when migrating north from the Patagonian nesting grounds to the wintering range. Monroe and Baron noted that 33 of the 40 observations were late summer through fall, which is the austral spring. Movement then should have been southward, not to the north. They concluded that an unheard of austral spring migration continuing in the same direction as the austral fall movement was occurring.

The records for 1979 to 1987 indicated that established trends in numbers, loca- 
tions and distribution continued into the 1980s. The incidence of reports increased again, to 16 , including a sighting in Quebec in 1982. ${ }^{8}$ Once more, most of them were in the northern Atlantic coastal zone in autumn. Only four were spring-summer and just one record, in Michigan, was from the interior. ${ }^{14}$ Four birds were adults, one an immature. Against this historical background, circumstances and records in 1988 were then considered.

American Birds regional reports for spring 1988 for the territory of interest were examined. ${ }^{1}$ The ten regions encompassing possible routes between South America and Alberta extended from the eastern Gulf coast and the Sonoran deserts north to the Prairie Provinces, and from the intermountain plateaus east into the Midwest. Four themes appeared in the reports: strong, sustained, warm southerly winds over most of the interior; continuance of extreme drought across almost the entire vast area; earlier-than-normal migrations and unusual numbers of southern rarities in most regions (for example, a tropical Great-tailed Grackle in South Dakota). ${ }^{2}$ Several editors attributed the two avian phenomena to the winds.

Weather maps for the last 10 days of May displayed a fluid pattern of continuous strong southerlies, with origin at one time over the Caribbean, at another over the Mexican deserts; although shifting between Midwest and intermountain Great Basin, the dominant flow was through the central plains. Except for brief local interruptions by westerlies in the American Southwest and northwesterlies in Alberta, wind direction varied from southeasterly (for example, across the Midwest to Montana) to southwesterly. Strong winds occurred at night as well as during the day and at low elevations as well as high. ${ }^{10}$

Five reports of Fork-tailed Flycatchers in North America in 1988 equalled the previous high. ${ }^{19}$ Following historical disposition, three were in coastal regions and two were in the interior: Alabama,
Virginia, Quebec (September 1988), Wisconsin and Alberta, 191320 Three sites were practically the same distance north, in a narrow band approximating $50^{\circ}$ north latitude: the Wisconsin bird at $47^{\circ}$, Drumheller's at $52^{\circ}$ and Quebec's on Anticosti Island at $49^{\circ} .{ }^{13}$ From the wintering grounds in South America ${ }^{12}$, which are $0^{\circ}$ to $10^{\circ}$ north latitude, these birds appear to have wandered half the distance from equator to pole. More germane, four of the five observations were in spring and summer; only the Quebec sighting was in autumn. ${ }^{13}$ This occurrence, a reversal of historical timing, suggests that these four birds overshot the austral autumn migration target.

In sum, several conditions were conducive to a Fork-tailed Flycatcher being in Alberta in spring 1988: some species abnormality caused flights northward and southward - far beyond the nominal range, southerly winds evidently drafted many rarities into the continent's interior, with warm, arid conditions possibly contributing to these movements and the wind pattern's southeasterly component may have displaced the forktail westward - without which shift it could have been another Thunder Bay or Wisconsin sighting. Although most fork-tails are reported from the Atlantic coast region, five records are in a band at $50^{\circ}$ north latitude, and thus the extent of the Drumheller bird's northward flight was not unique. Observations north of the Gulf coast region have increased in each recent decade, with 1988 being a high year, but, unusually, most of the finds were in spring. These several factors, however, could create only onehalf the observation; fortuitous or planned, the other half resulted from more birding, our presence in Drumheller so demonstrating.

There were two purposes for the Drumheller trip. One was to tour the new Tyrrell Museum of Palaeontology, a first-rate museum well worth a visit, and the other was to bird the Red Deer valley and adjunct coulees, a great place for birds. 


\section{Acknowledgements}

I gratefully acknowledge assistance provided by Kenneth E. Johnston, Atmospheric Environment Service, Saskatoon, and by staff of Canadian Wildlife Service, Saskatoon.

${ }^{1}$ BERKEY, G., B. GOLLOP, J.A. GRZY BOWSKI, T.A. IMHOF, H.E. KINGERY, G.W. LASLEY AND C. SEXTON, B.G. PETERJOHN, D.J. POWELL, T.H. ROGERS, D. STEJSKAL, J. WITZEMAN. 1988. Am. Birds 42, No.3.

${ }^{2}$ BERKEY, G. 1988. Northern Great Plains region. Am. Birds 42:453.

${ }^{3}$ COPLAND, H. 1988. Manitoba Museum of Man and Nature, Winnipeg. Pers. comm.

${ }^{4}$ DE SCHAUENSEE, R.M. 1970. A guide to the birds of South America. Livingston Publ., Wynnewood, PA. 470 pp.

${ }^{5}$ DICKSON, R. 1988. Calgary, AB. Pers. comm.

${ }^{6}$ FARRAND, J. 1983. The Audubon Society master guide to birding. Vol. 2. Alfred A. Knopf, Inc. 398 pp.

${ }^{7}$ GODFREY, W.E. 1986. The birds of Canada. Nat. Mus. of Canada. 595 pp.

${ }^{8}$ GOSSELIN, M. and N. DAVID. 1982. Quebec region. Am. Birds 36:958.
${ }^{9}$ IMHOF, T.A. 1988. Central southern region. Am. Birds 42:448.

${ }^{10}$ JOHNSTON, K.E. 1988. Saskatoon Weather Office. Pers. comm.

${ }^{11}$ MCGILLIVARY, B. 1988. Prov. Mus. and Archives, Edmonton, AB. Pers. comm.

${ }^{12}$ MONROE, B.L. and A. BARRON. 1980. The Fork-tailed Flycatcher in North America. Am. Birds 34:842.

${ }^{13}$ OUELLET, H. 1988. Nat. Mus. of Canada. Pers. comm.

${ }^{14}$ PETERIOHN, B.G. 1984. Middlewestern prairie region. Am. Birds 38:206.

${ }^{15}$ RIDGELY, R.S. 1976. A guide to the birds of Panama. Princeton University Press, Princeton, NJ. $394 \mathrm{pp}$.

${ }^{16}$ SALT, W.R. and J.R. SALT. 1976. The birds of Alberta. Hurtig Publ., Edmonton. 498 pp.

${ }^{17}$ SCOTT, S.L. 1983. Field guide to the birds of North America. National Geographic Society, Washington, DC. $464 \mathrm{pp}$.

${ }^{18}$ SHADICK, S.J. 1988. Saskatoon, SK. Pers. comm.

${ }^{19}$ TABER, B. 1989. Williamsburg, VA. Pers. comm.

${ }^{20}$ TESSEN, D.D. 1988. Western Great Lakes region. Am. Birds 42:1292.

\section{TURKEYS AT CLAIR, SASKATCHEWAN}

IAMES H. PURDY, Box 123, Frog Lake, Alberta. TOA 1 M0

At approximately 11:00 a.m. 29 December 1988, an unusual sighting was made from Highway 5 just east of Clair, Saskatchewan. Very close to the north side of the road, in a small grove of poplars, three large, dark objects appeared in the trees. As my vehicle approached the trees, my first impression was that these objects were raccoons; my next impression was porcupines; my third impression was black plastic garbage bags! As the car passed the small bluff, the objects moved, revealing that they were birds - large, dark birds. 